\title{
Muslim intellectual life in Eighth Century Baghdad: An insight of literature and poetry
}

\author{
Dr. Amt-ul-Rafi Muhammad Bashir ${ }^{*}$
}

\begin{abstract}
:
The second Abbasid caliph, Abu Ja'far al-Mansur, who is deemed one of the most significant caliphs of the Abbasid dynasty, created the city of Baghdad in a bid to create a capital for his dynasty that would give rise to a culture that surpassed in its intellectual and cultural prowess the Umayyads before it. It was this fixation of al-Mansur that led to his gathering the best litterateurs of his era around him in the newly constructed Baghdadi royal court. al-Mansur's city thrived after his death and became a cultural center of the world, giving birth to some of the greatest literary works of all time. This work is an effort to study briefly the formative eras of the stream of Arabic literature that was born in the Baghdadi courts \& streets - namely, from the year 763 C.E. (which was when the royal court was first held in the newborn city) till the end of the eighth century; the work begins with a brief look into the building of Baghdad as well as the caliphs who ruled it in this century, then the writer has discussed the elements that influenced the literature produced by the Baghdadi intellectuals in this era, before moving towards the two distinctive streams of poetry and prose along with a concise examination of the prominent poets and writers of Baghdad from the eighth century, and some important literary works (prosaic) produced in the city or that reached the city during this time. The work is concluded with a brief commentary upon the impact of the Baghdadi caliphs upon the literature produced under their patronage.
\end{abstract}

Keywords: Muslim, intellectuals, Baghdad, poets, literature, Islam

\section{Introduction:}

While much has been written about the literary genius that flowed out of the magnificent city of Baghdad, not much can serve as an introduction for a reader who is not acquainted with the formative eras of this literature. The latter half of the eighth century (specifically from 763 C.E. till the end of it) witnessed the birth of the city of Baghdad and the successful efforts of its founding father and his successors to turn it into a cultural center for

\footnotetext{
* Assistant Professor, Department of Comparative Religion, International Islamic University, Islamabad.
} 
their empire; the city saw creativity and intellect in its purest form in these years, housed some of the biggest geniuses of this time and produced some of the best literary works that have survived the test of time to be passed down to us today.

These pages are penned with the confidence that they will serve as an introduction for the reader into the Baghdadi literature produced in the second half of the eighth century; the work ahead begins with a brief introduction to the city itself and the monarchs that ruled it during the eighth century to give the reader a basic understanding of the historical context of the literature produced in eighth-century Baghdad, before it turns to the study of the literature itself; the historical elements that influenced it, the prominent poets and writers of this era, important literary works from the latter half of the eighth century and the effects of the caliphs upon the literature produced under their patronage have all been touched briefly, alongside snippets of Baghdadi poetry and historical anecdotes to make the read a pleasant one for the literarily inclined.

The methodological approach adopted by the researcher is a descriptive \& analytical one and a critique of the literary works named or extracted from has been avoided purposefully for fear of length, and because a literary critique of the giants mentioned in these works is an entirely new topic altogether.

The study ends with the researcher's personal commentary upon and examination of the common claim that the litterateurs of these formative years worked in the shadow of death because of the brutal religious policing of the conservative caliphs who ruled them, and that these caliphs could be qualified with nothing of the flowery praises bestowed upon them by their Muslim biographers of the later centuries.

\section{Literature \& Poetry in $8^{\text {th }}$ Century (C.E.) Baghdad:}

"Please tell those preferring abstinence, tell all considered to be pious:

Stay on the frontier, be modest;

Baghdad is not an abode for hermits.

Baghdad is a place only for kings, an abode solely for hunters and knights."

These verses, penned by Abdullah ibn Mubarak (726 - 797 C.E.) in his poem titled "The Pious Ascetic in Baghdad", have been chosen as an induction into this essay that deals with literature and poetry in $8^{\text {th }}$ century C.E Baghdad because they describe this city at the pinnacle of its development in its purest form.

Baghdad, built upon the orders of the $2^{\text {nd }}$ Abbasid Caliph al-Mansour, was 
a city that was created by men in search of places where they could gather roots.

In 762 C.E., al-Mansour was the patriarch of what was left of the Abbasid clan. With his allies rapidly turning into enemies and the younger princes like al-Mansour's own son al-Mahdi (who was notorious for his love of luxury) swiftly forgetting what it was like to live without palaces, courts and jewels, al-Mansour ordered for the foundation of Baghdad to be built and supervised the process of the building of the city keenly, which leads one to the aforementioned conclusion that this city was brought into existence with the hope that it would provide a stolid branch upon which the newly crowned Abbasids could build their cultural and political nest in an effort to create an empire that would last at least longer than their predecessors, the Umayyads, who had led the Muslim world for almost a hundred years before finally falling at the hands of the first Abbasid Caliph, al-Saffah (721 - 754 C.E.), whose name literally means He who causes the Gushing forth (of blood).

The city's building is said to have been finished in the year 762 C.E., while the Caliph officially started holding court there in $763^{2}$ C.E. after the completion of the royal Caliphal palace, the Qubbat-ul-Khazra' or the "Palace of the Golden Gate", moving into it with his family and initiating formally what would later come to be known as the "Golden Age of Islam".

In the eighth century, when this golden age was yet to begin, there were four caliphs in total who helmed the initiation of Baghdad's golden years as one of the most glorious cities in the world. These Caliphs, respectively, were:

1. Al-Mansour (714 - 775 C.E.) - the second Caliph of the Abbasid empire, the brother and declared heir of its founder al-Saffah, notorious for his religiosity and toughness. al-Mansour is known most for his founding and careful designing of the city of Baghdad, as well as his tightfistedness that bordered upon stinginess (he was awarded the title Abul Dawathiq or father of small change ${ }^{3}$ by his inferiors because of his "careful expenditure" of funds).

2. Al-Mahdi (744 - 785 C.E.) - son of al-Mansour; a handsome prince infamous for his love of luxury and his iron-fisted disciplining of the Zanadiqa or freethinkers (the holders of Manichean beliefs), alMahdi's era is not particularly marked by any literary achievements of consequence. Both him and his successor merely continued down the road paved by al-Mansour, but this may have been due to the timespans of both their reigns, which were much shorter than those of al-Mansour before them and al-Raschid after them. 
3. Al-Hadi (764 - 786 C.E.) - the elder son of al-Mahdi, who had a very short reign which was further troubled by his ambitious mother, Khayzuran ${ }^{4}$.

4. Haroun al-Raschid (763 - 809 C.E.) - who is deemed the wisest and most intellectual of all Abbasid caliphs. Haroun's greatest intellectual accomplishment, perhaps, was his patronage of the experts of the various streams of knowledge and art; he is said to have been the patron caliph of literary giants like Abu Nuwas, Abul Attahiya and al-Waqidi ${ }^{5}$ among other Abbasid litterateurs.

In the "golden age", Muslims entered all branches of sciences and arts via translatory works from the previous dynasties, using them as footing for their own eventual development in these same fields and thus providing to the western world the foothold for its ultimate development that would occur a few long centuries later; something that the Muslims themselves owed to the Greeks \& Romans primarily (and Persians, Indians and even the Chinese nation ${ }^{6}$ in general).

In this time, knowledge was "imported" from all corners of the world to be brought to Baghdad, translated and saved in the numerous archives the caretaking of which was funded by the Caliph himself. With this import of knowledge began also the gathering of persons of intellect and intelligence who were then brought to the court of the Caliph to be established under his patronage.

Among all of the many fields of knowledge, this piece is a small effort to provide an insight into two intermingling arts of literature and poetry, as produced in the Baghdad of the eighth century.

Historians and Litterateurs have divided the Abbasid Literature \& Poetry into two main eras: The First Era of Abbasid Literature and the Second Era of Abbasid Literature.

The early years of Baghdad understandably fall into the first era of Abbasid Literature and the latter years of the Eighth Century are some of the formative years of this era, among which we will deal with the Abbasid literature and poetry the date of the composition of which ranges from the year 762 C.E. (when Baghdad was built) to 800 C.E. (the end of the $8^{\text {th }}$ century).

The literature and poetry witnessed by the walls of Baghdad during the latter part of the $8^{\text {th }}$ century was subject to two major affecting elements:

1. The subjects, genres and styles chosen by the producers of these literary works; and,

2. The Caliphs ruling the Abbasid empire at the time of the production of these literary works

The impact of these elements may be criticizable to a reader who is new to 
the subject of Baghdadi - or even Arabic - literature \& poetry but if one is acquainted, even in passing, with this stream of knowledge and its relationship with the people who ran Baghdad in the eighth century (who were primarily Arabs by descent with the Ajamis or foreigners only acting as viziers, advisors and courtiers), one is aware of the deep and farreaching effects Caliphs tend to have on the poetry (especially) and the literature (generally) that is produced during their caliphhood just as one is aware of the classist divides of the Baghdadi society, where the commoner lived daily life with a religious zest the essence of which had been abandoned almost completely by the elite, which meant that the poetry of the commoner focused on subjects very different from that of the Elite poetry.

In an effort to rationalize the claim that caliphs affected (whether consciously or unconsciously is an entirely different debate!) the literature and poetry produced during their reign, the reader will be presented with three different anecdotes plucked from the reigns of three different caliphs, then s/he will be treated to a brief comparison between them and an examination of the underlying implications that these anecdotes contain regarding the roles of poets and litterateurs in early Baghdadi life.

The first anecdote is about a royal outburst witnessed by the courtiers of al-Hadi and runs thus:

"One day, we were in Musa (al-Hadi)'s presence who had with him Ibn Jami \& Mu adh bin al-Tabib. It was the first day that Mu'adh had ever come into our circle, he was an expert in singing melodies and very knowledgeable about the more ancient songs.

The Caliph said, "Whichever of you moves me the most to emotion, he can choose what he likes." So Ibn Jami sang a song for him, but it failed to move the Caliph. I knew what kind of songs made up his object of desire. The Caliph said, "Step forward, O Ibrahim," so I sang to him, "Sulayma has brought us together;/ But where, 0 where, can we say that she is?"

At this, he became transported with emotion, to the point that he rose up from his seat, raised his voice and exclaimed, "Sing it again!" So, I sang it again. He said, "This is the kind of song which is to my taste, so decide now what you want! "I said, "O Commander of the Faithful, the walled garden of 'Abd al-Malik and its murmuring spring." At that, his eyes rolled round in his head until they became like two gleaming red-hot coals. Then he burst out, "O son of a stinking, ********ed $w^{* * * * !}$ You wanted to let the people at large know that you were able to stir up my emotions and that I gave you your free choice and accordingly granted to you an estate! By God, were it not for the hasty error caused by your stupidity, which has clouded your sound judgment, I would strike off that 
which contains your eyes (i.e., your head)!" Then he bowed his head in silence for a brief while, and I had a vision of the angel of death standing between me and him awaiting his word of command. Then he summoned Ibrahim al-Harrani and told him, "Take the hand of this stupid fellow, and lead him into the treasury; \& then let him take from there whatever he likes." So, al-Harrani brought me into the treasury and said, "How much are you going to take? "I replied, "A hundred purses." He said, "Let me consult him (i.e., the Caliph)." He related, "I said, "Eighty, then." He replied, "(Wait) until I consult him." I thereupon realized what he wanted, so I said, "Seventy purses for me and thirty for you!" He said, "Now you have put forward the correct solution! Please go ahead!" So, I went away with seven hundred thousand dirhams, and the angel of death vanished from before my face."

Thus, runs the first anecdote about Ibrahim, a poet who in all appearances, had appeared to have been gaining the Caliph's good graces but had lost them in a moment with a single slip of tongue that had brought him, in his own words, under the shadow of the angel of death.

The anecdote, while narrated in a darkly comical way with descriptions like eyes rolling into the back of his head and the callous likening of the Caliph to the angel of death, is in fact a very dark story that sheds ample light upon the peril poets must have been at in the Abbasid courts, being at the absolute mercy of every new whim and mood of the Caliph.

It also shows the ease and entitlement with which poets and litterateurs were manipulated by the other courtiers, almost as if the intellectuals "owed" a part of their success to them, the courtiers. It may be a safe guess to venture that this entitlement stemmed from the idea that the intellectuals had life "too easy" for themselves and therefore, their coattails had to be ridden by the less fortunate; namely, the officials with predetermined salaries.

The second anecdote is plucked from the life of al-Mansour and it goes thus:

"On one occasion a poet came to al-Mahdi, who was then heir apparent, at Rayy, and recited a panegyric in his honor. The prince gave him 20,000 dirhems. Thereupon the postmaster of Rayy informed Mansur, who wrote to his son reproaching him for such extravagance. "what you should have done," he wrote, "was to let him wait a year at your door and after that time bestow on him 4,000 dirhams." He then caused the poet to be arrested and brought into his presence. "You went to a heedless youth and cajoled him?" "Yes, God save the commander of the faithful, I went to a heedless, generous youth and cajoled him, and he suffered himself to be cajoled." "Recite your eulogy of him." The poet obeyed, not forgetting to conclude 
his verses with a compliment to Mansur. "Bravo!" cried the caliph. "But they are not worth 20,000 dirhams. Where is the money?" On its being produced, he made a gift of 4,000 and confiscated the remainder." 8

This story centers more upon the Caliph in question than the poet (whose name is not alluded to even in passing by Nicholson in his A Literary History of the Arabs but can be found in al-Tabari's account ${ }^{9}$ of alMansour's time and is said to be either Ibn Marthadd or Hassan alKhwarizmi) and sheds light mainly upon the attitude of one present Caliph and one future Caliph towards the same poet. It also serves to show, like the first anecdote, how unanticipated life as a poet or litterateur was in Early Baghdad and demonstrates just how volatile a career poetry or literature presented to one.

Moreover, it reveals the effect the little formalities and etiquettes of courtly life tended to have on the work of the poets and litterateurs (look, for example, at the line stating that the poet added to Mahdi's ode a few words in honor of al-Mansour in order to either please him or at least, to not offend him).

The third anecdote is not an anecdote at all but a few verses lifted from the poetical advice of Yahya al-Barmaki, to his son Fadl;

"Seek glory while 'tis day, no effort spare,

And patiently, the loved one's absence bear;

But when the shades of night advancing slow,

$O$ 'er every vice a veil of darkness throw, Beguile the hours with all thy heart's delight,

For the day of prudent men begins at night."10

Al-Barmaki (who died in 805 C.E.), described as a graceful man with "wisdom, nobleness of mind and elegance of language", held important offices during the reigns of both al-Saffah and al-Mansour and was promoted to the seat of the Grand Vizier under the reign of Haroun alRaschid. Outwardly a most pious man, there were whispers in the court of al-Barmaki's characteristic Persian love (for he was of Persian descent and very proud of it) for Philosophy which resulted in the nightly gatherings of freethinking scholars and prominent heretics in his home. It was years later that Haroun al-Raschid would resolve to rid his court of the entirety of the Baramika clansmen and would even have Yahya's son Ja'afar, a very close companion of his, killed. ${ }^{11}$

These three stories when placed side by side on the dusty pages of history, pose a very interesting and simultaneously intimidating picture of the Baghdadi poetic and literary scene in the formative years of the Abbasid Empire.

A keen observer sees witty men wrenching their dues from the hands of 
Caliphs and their corrupt officers, and wittier Caliphs wrenching back undeserved rewards from the hands of whom they deem greedy pseudointellectuals. A keen observer sees a jolly reminder from a father to a son to adhere to his duties in the morning that he may devote the nights to his pleasures, a jolly reminder to a poet that his "spoils" from the intellectual wars he fights in court will be tactfully targeted by the cultured hyenas roaming the tiled floors of Baghdad's palaces.

A keener observer, however, notes something far more ominous lurking beneath the cheerful narration of these "anecdotes" and pieces of poetical advice.

A keener observer looks past the comical aspect of Ibrahim's expressed desire and the caliph's angry lashing out upon hearing it and tastes the steely tase of fear on the tongue of a poet who is realizing too late that his demand - voiced upon the order of the Caliph himself - could have offended his caliph enough for him to want to mortally hurt him. The keener observer sees the old poet's mind whirring in an attempt to find a way out of this latest predicament thrown his way by the Caliph and is subjected to the anxiety-inducing realization that if the Caliph had been in a worse mood, or if Ibrahim had not been able to understand the clues tossed his way by al-Harrani, he could very well have not walked out of the royal palace alive that day.

A keener observer, similarly, makes note of the anonymous poet changing his verses to include al-Mansour's praise alongside his favorite son Mahdi's because an ode to the young prince in the presence of the Caliph could very well be interpreted as a sign of fealty to the young prince and a subtle expression of the desire of the young Prince's enthronement (and thus, the current caliph's dethronement).

With these new observations in mind, when one rereads Barmaki's verses of advice to Fadl, one feels that they are laced with the fear of being 'found out', that there are things the Grand Vizier does that must be done only in the darkness of the night for the daylight brings with it the minions of the court and its many members who scurry the streets of Baghdad in the search for something with which to sully the reputations of their masters' enemies in court.

While poetry inside the courts was subject to the whims of the caliphs and the wit of its producers with its genres ranging from hunting poetry to love poetry all deemed exclusively elite genres of the art, there was another form of poetry that was budding in - and that roamed - the streets of the great city of Baghdad, and it was this poetry that depicted what life was for the Baghdadi layman.

A very good specimen of such poetry would be the piece that served as an 
induction for the reader into this work, which can now be reread with greater comprehension that was penned by Abdullah ibn Mubarak, a wellknown scholar of the eighth century:

The Pious Ascetic in Baghdad

"Please tell those preferring abstinence, tell all considered to be pious:

Stay on the frontier, be modest;

Baghdad is not an abode for hermits. Baghdad is a place only for kings, an abode solely for hunters and knights."12

In these lines, one notices something extremely different to the careful, flowery advice of al-Bermiki to his son. There are undertones of weariness to these lines. One senses a sigh of frustration intertwined with the words as the poet urges his reader to abandon what is known as the Greatest City of the Abbasid Empire and go to the Frontiers of the Empire, namely Hijaz, if the reader is inclined towards a life of asceticism and modesty for the kings, the hunters and the knights maintain too strict a hold upon the streams down which the culture of Baghdad flows for there to be adequate space for the hermit, the beggar, the "pious ascetic" to flourish in the large city.

This stark difference between the poetry being produced in the shadow of the luxurious court and that being produced in the bazaars of Baghdad owes its existence to the difference in the lives of the Baghdadi elites and the common population of Baghdad.

The elite lived a life of luxury, excitement and intrigue, with no care for religious restrictions upon things like wine which were as of yet something divinely prohibited to the common man who still bore a great deal of reverence for Islam and Islamic values.

The jeunesse duree of the Baghdadi elite was obsessed with creating and following the latest fashions in music and song and resided in lustrous palaces overlooking the Tigris ${ }^{13}$ that were managed by armies of servants and chamberlains.

In all of the elitist Baghdadi lifestyle, one notices deeply embedded a Persian "touch", and this Persian touch that is synonymous to luxury, wealth and trend is nowhere to be found in the life of the common Baghdadi man, which is exactly why this same Persian flare can be traced in the poetry that found its home under the Caliph's patronage but is absent in the "street poetry" of Baghdad.

It would be unfair at the very least to say that the Baghdadi poetry produced under the personal patronage of the Caliph - infamous for its highbrow ostentatiousness and delicately-worded quality - is created 
essentially by this Persian flare. In fact, the style in question is purely that of Baghdadi birth. What the Persians in the caliph's court can be credited with in their influence upon $8^{\text {th }}$ century Baghdadi "court poetry" has been summarized by Nicholson as following:

What the Persians brought into Arabic poetry [...] (was a) lively and graceful fancy, an elegance of diction, depth and tenderness of feeling and a rich store of ideas. ${ }^{14}$

Before one switches back to examine what has been termed as "Street Poetry" in the lines above, one deems it advisable to linger upon "Court Poetry" and introduce to the reader a few of its specimens as well as their producers.

In order to examine the stream labelled as court poetry, it is important for the reader to be familiar with a term used for a certain group of poets in Baghdad; "Majuneen" Majun literally means the promiscuous!).

The poets in the courts of Baghdad prided themselves on being a part of this group of men, who lived life a day at a time and who believed in no god but a glass of wine, a good tune struck on a tambura and the longing gaze that lingers at the gentle curves of a dancing concubine.

Among them, two of the most infamous $8^{\text {th }}$ century poets remain to be Abu Nuwwas and Muti' Ibn Iyas.

In order to understand the enigma that was Muti' Ibn Iyas, a very brief dive into his poetry is unavoidable. For this purpose, the work most reflective of Ibn Iyas' attitude towards poetry, his choice of subjects and his style is a relatively obscure poem written in description of a rendezvous of his in the Baghdadi streets on a fine morning which runs thus:

\author{
Stars Whirling in the Dark ${ }^{16}$ \\ It was morning in Baghdad, we were carousing, \\ stirred by a white face and deep-black eyes. \\ In a house where glasses are akin \\ to stars whirling in the dark among drinking companions. \\ Our cupbearer mixed wine or served it pure; \\ what a wonderful wine when mixed! \\ Saffron powder was sprinkled over us, \\ above our heads, crowns of golden jasmine. \\ I was still drinking when sunset arrived, \\ between melodies of castanets and lute.
}

The subject of wine and the intricate descriptions of it and the varying elements surrounding its drinking are all characteristic of the Majuneen and thus Ibn Iyas. 
Born \& raised in Kufa, Ibn Iyas started his poetical career as a poet in the Umayyad court and was a boon companion of the Caliph Walid ibn Yazid. Later, after the downfall of the Umayyads, he entered the Abbasid court and found his place near al-Mansur by way of his younger son Ja'afar who took to the poet in spite of the rumors surrounding his licentious lifestyle and the fact that his company outside court consisted of freethinkers or Zanadiqah. $^{17}$

Ibn Iyas' poems are not as flowery as the typical court poetry of the early years of Baghdad. His style is unassuming, original and reads as blithe, to be honest, for a man who has seen and experienced the life-threatening intrigues of the double-edged sword that is the Baghdadi court life, firsthand.

Ibn Iyas, who had never really been able to accept the fact that his beloved Umayyads had been overthrown by the Abbasids, had a sense of humor that was prone to testing this double-edged sword of court life in fact, and he is described as having been "an Umayyad among the Umayyads and a staunch Abbasid among the Abbasids." "18

Sometimes, however, the façade would slip and Muti's jokes would come home to roost. A great example of this happening is recounted in Hadeeth ul Arbia'a ${ }^{19}$ thus;

Al-Mansour decided to declare al-Mahdi heir after himself and his son Ja'afar was objecting to this. So, one day, al-Mansour assembled the populace and the poets and speakers praised al-Mahdi and spoke in admiring tones of the young prince. After all of their praise and worship, Muti' came unto al-Mansour and said, "O commander of the faithful, I have heard from authentic narration linked to the Prophet himself that he (peace be upon him) said, "al-Mahdi will be of my stock, and he will fill the earth with equity and justice as it was filled with oppression and tyranny." And this, your brother, Abbas ibn Muhammad, too, has witnessed this." Then, Muti' turned to al-Mansour's uncle Abbas and asked him, "Upon the God who has created you, is it not so?" the old uncle, who quaked from the Caliph's fear, agreed at once to having heard the Hadeeth Muti' had fabricated upon the spot, and al-Mansour ordered that al-Mahdi be declared the heir to caliphhood.

The story does not end here with Muti's obvious imprudence when it came to religion and his clear disdain for and manipulation of al-Mansour's alleged religiosity, but continues with Mahdi gaining permission from his father to call the old poet to account for his lies and "fisq" - debauchery. This accounting Muti' escaped with a tearful speech about his loyalty to the Abbasid clan and he escaped not only with his life saved but also with a reward of hundreds of Dinars from al-Mahdi, all for his "services" to the 
royal family. ${ }^{20}$

This story is enough to show to the reader the way-ward ways of this poet, who was a Mujawwin to the core. Muti' ibn Iyas, throughout his long life and his literary services to two of the best courts to ever be seen on the face of the Earth, dabbled in many genres but his best creative foot was put forward in his love poetry, which is said to have been the most delicate and profound of all the love poetry written and recited in the Abbasid court.

One of his most famous love poems that depicts his style and choice of subject in that genre perfectly is "The Yeoman's Daughter", a piece consisting of his lamentations upon the separation forced between him and his beloved, the daughter of a Dihqan - a yeoman or farmer in simpler terms.

Muti' died between 785 C.E. or 787 C.E. in Baghdad, apparently of some sickness the details of which remain unknown. ${ }^{21}$

The second crucial member of the Majuineen is Abu Nuwwas. Born sometime in the middle of the $8^{\text {th }}$ century, this Bacchic poet was from Ahwaz and was of Persian descent ${ }^{22}$. He arrived in the court of Haroun alRaschid after he had received education in both Kufa and Basra ${ }^{23}$, two distinguished centers of knowledge in the Abbasid empire, and quickly created his own niche in the court of the fifth Abbasid Caliph.

In all honesty, this niche was not, perhaps, one to be envied. A man with a flagrant disinterest in religion and a man who was prone to displays of immorality, drunkenness and blasphemy, Abu Nuwwas created his niche in court at the price of exciting Haroun's anger on his bad days. It is quoted that Haroun imprisoned Abu Nuwwas several times because of his unruliness ${ }^{24}$. However, Abu Nuwwas was destined to survive both Haroun and his son Amin and therefore came out with safe hide and hair from these random imprisonments, once even belligerently declaring to the young Caliph, "If you kill Abu Nuwwas, where will you find another?!",25 Abu Nuwwas was the one Abbasid poet bold enough to dabble in every genre of poetry ${ }^{26}$ from the ancient qaseedeh to elegies, satires, panegyrics and ghazals. In an effort to give to his work the stylistic touch of the Arab poets of yore, Abu Nuwwas spent a year in the deserts of Arabia ${ }^{27}$, studying the pure Bedouin Arabic from its masters. It was perhaps this depth in Abu Nuwwas' craft that held Haroun al-Raschid back, forcing the Caliph to endure the poet's eccentricities to sustain and nourish his talents. Towards the end of his life, it is said that the poet had started down the path to remorse which is found well-expressed in the poetry from the last years of his life in Baghdad. He died in 810 C.E. after getting roughed up because of a joke he made at the expense of an unnamed member of the 
Bani- Naubakht clan ${ }^{28}$.

A work of his that mirrors his personality the most, perhaps, is titled Pilgrimage $^{29}$ which sheds much light upon his chief interests in Baghdad. The poem is a flagrant exhibition of his knowledge of the city's murkier areas. Penned by the younger Abu Nuwwas, it runs thus,

People say, do you want to make the pilgrimage?

Of course, I say, only after Baghdad's delights expire.

Those of Qatrabbul included, and Qubbat al-Firk, district of Kalwadha.

Al-Salihiyya too, also al-Karkh where

Baghdad's strangers gather - for me they are not strangers

How can I leave for Mecca, being still deeply engrossed in a madam's brothel or in a tavern?

Let us say you save me from the pleasures of Baghdad, but how can I free myself from Tayznabadh? ${ }^{30}$

With the words of Abu Nuwwas shedding ample light for the reader upon what was considered court poetry in eighth century Baghdad, it is only required to introduce the reader in passing to some other important names from Baghdad's court poetry; some well-known poets who made their way to the courts of Baghdad after the city's creation are:

1. Marwan Ibn Abi Hafsa (721 - 797 C.E.) - who came to Baghdad from Medinah and whose craft was utilized mainly in panegyrics composed in the honor of al-Mahdi and al-Raschid. Marwan was wellknown for his stinginess and sparing lifestyle. ${ }^{31}$

2. Abu Dulama (who passed away in 778 C.E.) - whose main occupation was that of a court jester and whose poetry was usually only Haja' or derision at everybody around him including himself. Abu Dulama was an Abyssinian who had fought in the battle against the Umayyads and had later been permitted into the court as a permanent member after composing a eulogy in praise of al-Mansour's murder of his ally Abu Muslim. ${ }^{32}$

3. Bashshar ibn Burd (693 - 783 C.E.) - a blind poet who had starting reciting poetry at the tender age of ten, Bashshar was a marked Zindiq or Manichean whose beliefs were boldly reflected in his poetry. He was a Persian - probably a royal one - and had incensed the staunchly Arab Abbasids on more than one occasion with his jibes at the superiority of his race over the Bedouin Arabs, who he asserted were an inferior people who "ate lizards and rode camels in the desert ${ }^{33}$ ". Bashshar died of seventy lashes at the age of ninety, a punishment which he was subjected to for having written poetry insulting an Abbasid minister. ${ }^{34}$

With court poetry out of the way, one can now turn to what has been mentioned hitherto as "Street Poetry"; poetry that was written by men who 
did not frequent the court and whose poetry catered to the commoners, who chose subjects that the common population of Baghdad could relate with - and by now, the reader is sufficiently aware of the difference between the interests of the elite and that of the general populace in Baghdad.

The street poetry dealt with religiosity and with asceticism; it talked about the cruelties of this world and the fears that fettered men as they went about living their daily lives.

One of the best poets to wander the streets of Baghdad with this form of poetry on his tongue was Abu Al'Atahiya, a Hijazi who had recited poetry from his childhood.

Al'Atahiya, who had not received a formal education - a fact that accounted for his nonconforming style - started his poetical career with love songs or Ghazals which garnered such praise and admiration among his Kufi audience that the young man set out to present himself to alMahdi $^{35}$, who was then Caliph of the Abbasid Empire.

Al'Atahiya was welcomed at Mahdi's court and rapidly gained the Caliph's favor but his career as a court poet came to a swift end when he fell in love with one of Mahdi's slave-girls, Utbah, who did not reciprocate his feelings. It is said that Utbah's coldness drove Abu Al'Atahiya to his subsequent life of "zuhd" 36 or asceticism and denouncing the luxurious life and the literary niche he had created for himself at al-Mahdi's court, the poet left both Utbah and the ghazals he had built his career upon behind him and started writing what would eventually come to be known historically as his real literary niche; the "Zuhdiyaat", poems about asceticism and the denouncement of this world and its pleasures.

While Abu Al'Atahiya's defeat in the amorous battlefields was what gave him the professional direction that would prove to be his biggest success, the story of this defeat is a sad one that one cannot read but with the wish that the poet had somehow succeeded in charming the young Utbah. It is recounted, however, that Utbah had been so distressed by Abu Al'Atahiya's lamenting of her cruelty, her hard-heartedness and her flirtatious, mercurial nature that she had wept to the Caliph al-Mahdi and his wife, Khayzuran, asking them to put a stop to the poet's praises of her beauty and mourning of her ruthlessness.

Al-Mahdi had summoned the witty young Abu Al'Atahiya and had unsuccessfully attempted to put an end for once and for all to the unnecessary and undesired advertisement of Utbah's love life in the Baghdadi court.

Abu Al'Atahiya, however, had not stopped and upon this disobedience, had been beaten upon the Caliph's orders. As he was being punished, 
Utbah happened to cross by and greatly upset at his condition, ran to alMahdi to beg for his forgiveness. al-Mahdi promptly forgave him and sent him 50,000 dinars as a peace-keeping gift.

Abu Al'Atahiya, however, instead of keeping the gift as was the norm for court poets, gave away all the money at the gate of the palace. When the Caliph inquired into the reason behind his not having kept the money, the smitten young man replied, "I would not have wanted to profit from my love." 37

The two were separated nonetheless, however, because Utbah may have displayed mercy but she was never in love with Abu Al'Atahiya and Abu Al'Atahiya would not have had life in court any other way, and so the story goes, the young poet left the court and started reciting his Zuhdiyaat. In Haroun al-Raschid's reign, Abu Al'Atahiya earned the Caliph's wrath for his alleged expression of the beliefs of the Free-thinkers - the Zanadiqah - in his poetry and was allegedly imprisoned by Haroun, only freed under the condition that he restart writing ghazals ${ }^{38}$.

Abu Al'Atahiya outlived Haroun, however, and continued writing in the strain he had chosen for himself, until his death in the Caliphate of Mamun al-Raschid ${ }^{39}$.

Below is a selected and culled piece from Abu Al'Atahiya's Zuhdiyaat to give the reader a clearer insight into the poet's style and choice of subject:

Get sons for death, build houses for decay! All, all! Ye wend annihilation's way. For whom build we, who must ourselves return, Into our native element of clay? O time, inconstant, mutable art thou, And o'er the realm of ruin is thy sway. What ails me, that no glad result it brings, Whenever, $O$ world, to milk thee, I essay? And when I court thee, why dost thou raise up On all sides only trouble and dismay? As if no punishment I had to bear, A load of sin upon my neck I lay; What argument allege, when I am called To render an account, on reckoning -day? ${ }^{40}$

It is important to note, however, that Abu Al'Atahiya's poetry - however ascetic and stylistically variant from the Baghdadi court poetry - remains marred with accusations of Manichaean undertones and underlying Zindiq beliefs $^{41}$, a charge that is laid against him to this day by Orthodox critics who take note of the absence of the mention of resurrection in his work as well as his belief in God having created the universe from two singularly 
opposite elements which would be what the universe would eventually be reduced to, too, and other such ideas ${ }^{42}$.

The fact remains, however, that Abu Al'Atahiya was one of the greatest poets to live in eighth century Baghdad, part his way from the devious courts, witness the developmental years of the city's golden age and above all, leave his own extraordinary mark upon the poetry that was born in this city to pierce through the veils of age and time to reach us today.

Poetry is not all, however, that has pierced the veils of time to reach us from the Baghdad of eighth century Iraq. There is also prose, and prose of varying sorts at that, but while tracing prosaically inclined literature to the $8^{\text {th }}$ century, an important observation that one must keep in mind is one that has already been mentioned in this work; that Baghdad was the brainchild of al-Mansour, a man who wanted to create and nourish an entire culture that could spread across the Muslim world like that of the Umayyad empire before his own empire, and so much of the prose we see in $8^{\text {th }}$ century Baghdad, at least, is "acquired" prose - prose that has been borrowed from the Greek \& Roman works of yore.

That is in no way a statement meant to demean the acquisition or make it out to have been something simple and academically unchallenging to do. On the contrary, this acquisition of great literary works, which is uncreatively dubbed the "Translation Movement" ${ }^{43}$ ", was a long and complicated process that included the labor of not only Abbasid ${ }^{44}$ Academics and Scholars but also that of the Greek, Syrian, Sanskrit and Pahlavi translators employed to translate the works of their languages into a passably comprehendible Arabic version which would then form the basis of the Arabic reproductions helmed by the Abbasid scholars. ${ }^{45}$

Hitti, interestingly, when discussing these acquisitions into Abbasid literature, dubs this the "Intellectual Awakening" of the Muslims, a name with severely dissimilar connotations to the "Translation Movement", the name adopted by Mallette in her discourse on the same in her essay "The Metropolis and its Languages".

The two names, however, both sit right if taken literally, upon this age. It was during this period that Muslims across the empire first came into touch with the works of academic sages like Aristotle and Galen and it was through a tedious process of academic translation that this happened.

It is important to note that these translated texts came with accretions that had been added to them over the ages by the different translators and commentators of them; this was not a negative point and in fact, served to modernize these texts and give the Abbasid translators a chance to review the changing sensibilities of the people these texts had passed through the hands of, over the ages. ${ }^{46}$ 
The Abbasid academicians, in their turn, preserved these commentaries on these texts alongside the original texts and throughout the "Translation Movement", this acquisition of foreign literature - ranging from the social sciences to the natural ones - did not stop with one translation, rather continued with several updated translations of the same works with added commentaries introducing new professional terminologies as well as new developments in the relative fields.

While the $8^{\text {th }}$-century works in Baghdad are of varying kinds and cover diverse topics, the ones it is most important to include in an essay about the literature of that era are those that come under the literary division of belles-lettres and translated literary works; a notable such work that was originally produced in Basra but had conscious effects on the court in Baghdad is the Kalilah \& Dimnah, the Arabic version of the Hindi Tales of Bidpai, a large compilation of tales within tales within tales that was originally written by Vishnu Sharma ${ }^{47}$ and was translated by the Persian Ruzbih, also known as Abdullah bin Al'Muqaffah ${ }^{48}$.

I say the Basri work had far-reaching impact upon the Baghdadi courts because the themes of many of the tales told within this work by the many characters had morals directly related to the courts; in example, the tale of the two titular characters, the jackals named Kalilah and Dimnah, in which Dimnah becomes jealous of the King (Lion)'s advisor, a bull named Duke the Beef $^{49}$, who has taken up Dimnah's position (after a previous story in which the jackal himself introduces him to the king's court, understanding how advantageous the wise bull could prove for the lion) as the King's special advisor in court and hatches a plan to get the king and the bull to confront each other, each believing the other intended to harm him, so that Dimnah's position and power could be restored. When Kalilah finds out about Dimnah's plot, he tries to talk his brother out of executing this nefarious scheme through storytelling (a method commonly employed among the many diverse characters of Kalila and Dimnah) but fails to dissuade his brother.

Eventually, the bull is killed but when Dimnah tries to convince the king that he had been right in killing the bull who had allegedly challenged his authority, the king retires to his cave without replying. The tale ends with the ominous foretelling of the effect of the bull's murder on the king with the sentence "and while some lived happily, others did not". The direct moral one gleans from this tale is that of the far-reaching effects of petty court intrigues that these apparently harmless deceptions can end in murders of innocent people and in the despondency of a ruler whose hand has been forced against his own best instincts ${ }^{50}$.

To support this moral's - and this piece of literature's - connection with 
the royal court in Baghdad, the reader is presented with two important pieces of evidence.

The first is Hitti's claim in his History of the Arabs that the Kalilah and Dimnah had served as a guide to instruct the Abbasid princes in the "Laws of Polity" 51 which shows that this translated work of genius did reach the courts in a literal sense.

The second piece of evidence is the resemblance this story bears to the historically recorded one of the fall of the Baramika in the court of Haroun al-Raschid, where before they had been held in the highest esteem by the Caliph, to the extent that in the tenth-century fictional work The Arabian Nights or the Thousand and One Nights, the fictional version of Haroun's closest advisor and friend is Ja'afar Barmaki, an imaginary version of the eighth century vizier who was murdered by the Caliph in cold blood after accusations of having had an illegitimate affair with Haroun's sister Abbasa $^{52}$. Ja'afar's entire family, too, had been expelled around the same time from the court. ${ }^{53}$

Later, however, Haroun al-Raschid had come to realize that those who had played the biggest role in driving the Baramika from his court were perhaps the very ones who had worked hard to create the reasons for their expulsion in the first place and, it is said, that whenever the Baramika were remembered in a derogatory manner in his court after their dismissal, Haroun would recite Hutaiy'a's ${ }^{54}$ famous verse which ran thus in an effort to silence their insulters:

\section{"O Slanderers, be your sire of sire bereft, Give o'er or fill the gap they have left!"}

This fall of Ja'afar Bermiki can be found mirrored in the tale of the King Lion and Duke the Beef, and this reflection of the events in a fictional work is made all the more ominous by

1. The moral gleaned from the story of the harm court intrigues did to the king; and,

The foreshadowing of the possibility of a dismal end for the Baramika in Baghdad at the hands of their jealous inferiors as written in the verses addressed by Ja'afar's father to his brother, Fadl:

"Who but a fool his pleasures would expose,

To spying rivals and censorious foes?",55

Alongside the Kalilah and Dimnah, which might have been the first fictional work to be acquired into the literary treasure trove of Abbasids in eighth century Baghdad, there were countless other works - mostly of non-fiction - that were translated during the early decades of the Translation Movement in the late $8^{\text {th }}$ century in Baghdad.

Two notable works - of their respective fields - that one can conclusively 
trace back to the city of Baghdad in the $8^{\text {th }}$ century are:

1. The Siddhanta - a treatise on astronomy which entered the empire upon the shoulders of an Indian traveler in 771 C.E., and was "acquired" by the translator al-Fazari upon the order of al-Mansur; al-Fazari, who passed away in 777 C.E., later became the first astronomer in Islam ${ }^{56}$ and was the first Muslim to construct an astrolabe. ${ }^{57}$

Sirat Rasul Allah - a historiographical work by Muhammad Ibn Ishaq (who died in Baghdad around 767 C.E.) of Medinah, whose grandfather had been among the Christian children captured by Khalid ibn al-Walid at Ayn al-Tamr. This biography is preserved only through its ninth century recension penned by Ibn Hisham who died in Cairo, Egypt, in 834 C.E. ${ }^{58}$ The glory of the works of Ibn al-Muqaffah - who was a Zoroastrian convert to Islam who was later burned to death by the Caliph al-Mansour in 757 C.E. under suspicions of heresy ${ }^{59}$ - may have reached the Abbasid courts from afar but there were yet other litterateurs academically active within the folds of the Baghdadi elite. An important name that is distinctively Baghdadi in life and style is that of Salam al-Abrash (the title literally meaning The Speckled), a eunuch who had served al-Mansur as his page ${ }^{60}$ during his childhood and who was later among the chief courtiers in Haroun al-Raschid's court and apparently hired as the "Chief of the Eunuchs" $" 61$ at the royal palace to boot.

Salam's naam is mentioned in passing in al-Nadim's Fihrist as one of the earliest translators - "Nuqala'u al-Qudama'a"62 - and to him is ascribed the translation of the Physicia Ascultatio or the "Natural Hearing".

Salam al-Abrash's name also appears in the literary history of eighth century Baghdad as a patron of literary talents in the exhilarating story of Ibn Jami, a poet who was banished from Baghdad by al-Mahdi ${ }^{63}$ for having disobeyed his order to stay away - singer that he was - from the two princes, Harun and Musa (al-Hadi).

There are also other unnamed translators who translated many Greek, Byzantine, Pahlavi, Persian \& Syrian ${ }^{64}$ tracts into Arabic upon the personal bidding of al-Mansour which means it can be conclusively said that these works - which included the Euclid and Ptolemy's Almagest were translated in the $8^{\text {th }}$ century in Baghdad.

\section{Conclusion:}

There were doubtless many who contributed to what would come to be dubbed as the "Intellectual Awakening" of the Muslims in the early decades of Baghdad's founding. However, it with great dejection that one is forced to acknowledge the nonexistence in those decades of imperative foundations like the Bayt al-Hikmah (the House of Wisdom; a library 
founded in the ninth century by al-Mamun (the son of al-Raschid) ${ }^{65}$ in which great literary gems were preserved under the eye of the Caliph alMamun and his intellectually-inclined successors) led to the loss of a great number of these gems and so, as one passes from page to page of the literary histories of the Abbasids' first century in power, one has to turn many pages and pore over many books before finally stumbling upon a name, a date, a book or an anecdote that leads one down a wearisome rabbit hole as exhilarating as it is tiring (very much like the rabbit hole Alice jumped into, in Lewis Carrol's Alice's Adventures in Wonderland) that ends in the finding of a poet or litterateur who lived in eighth century Baghdad.

This pessimistic observation brings the reader to the end of the present research and opens the gate for them toward a few concluding observations that it is deemed crucial to note here, the first of which being that the role of religious authoritarianism in early Baghdadi literature is one so great that it makes a reader of Baghdadi literary history fear that the literature that has reached us today from the Baghdad of the eighth century C.E. is divisively misleading; there are accounts of some poets, especially, for they seem to have awakened the wraths of the Abbasid caliphs more than the prose-writers (owing perhaps to the obvious preference Arabs had for poetry over prose and thus their subsequent belief in its effects on the general populace), having been denounced as free-thinkers or "too philosophical", like Abu Al'Atahiya and Ibn Jami, who faced pressure of varying kinds to change their style and stream of poetry, with the latter facing banishment and the former, imprisonment. When these accounts are placed alongside accounts of the same caliphs opening their arms to litterateurs whose views are, in all appearances, extremely discordant with their own views, one is forced to wonder which shade of these Caliphs a reader studying early Baghdad ought to be more accepting of. Is the kinder, more tolerant shade a white-washed historical version or is the strict authoritarian side, an orientalist perception of the Caliph's personality?

It is difficult to choose any one answer completely, one must admit, and at the end of the day, this city that was created by the Abbasids to "gather roots" as it has been observed before, was a city that was not kind to them; they faced betrayal within the walls of their homes, the large castles bordering the Tigris that they had built with such care, and so the irrationality in their behaviors towards their courtiers, while it cannot be justified, can be understood. In fact, it can be understood best, perhaps, in this verse about the city by an anonymous poet that was discovered during the author's readings for present work, and which comes to mind now as 
these concluding thoughts are committed to paper;

"It is a land where men's souls are sick.

The stench even stronger when it rains. "66

Another vital thing that must be mentioned before the conclusion of this work is a passing comment upon the Shu'ubiyyah Movement, an AntiArab (and simultaneously Pro-Arabic) movement that rose parallel to the "Translation Movement" in the east of the Abbasid Empire ${ }^{67}$.

During the latter years of their Caliphate, there had been bitter whisperings of the Umayyads' nonchalant and belligerent promotion of the Arab Elite and their obvious preference for them above the other nationalities that had at this point in history, become a regular and permanent part of the Islamic empire.

Despite the Abbasids' tall claims to change this, change proved difficult and slow (even though the Abbasids had welcomed their Persian allies to their courts from Day one of their empire), much to the chagrin of their Persian and Nabatean subjects, who created what Mallette terms the "Avant-garde of cultural resistance to the Arab Dominance" in literature.

This movement, and the underlying threat it posed to the extremely Arab Abbasids, ties in directly with the fear expressed in the first observation presented to the reader; that the authoritarianism noticed among the Abbasid Caliphs may have been more than mere religious zeal. It could have been a systematic quietening of dissident voices among the poets of the nation, for it was the poets, it is reiterated, whose voices could reach the farthest corners of the Islamic empire by way of the tongues of the general populace.

The narrative supporting this hypothesis is that of Bashshar Ibn Burd, a poet who, if it had not been for his Shu'ubi fanaticism, could have perhaps counted amongst the best poets of early Abbasid era in Baghdad ${ }^{68}$.

His Shu'ubi leanings, however, eventually provided his death certificate, and he was executed in al-Mahdi's era on accusations of - and this is what interesting - heresy or Manicheanism ${ }^{69}$ (much like the allegations that led to al-Atahiya's imprisonment) and not non-Arab sentiment as one tends to suspect after studying Bashshar's life and political preferences.

What it was that gave to Baghdad the cloak of intrigue and mystery the city shrouded itself into for the subsequent years of its foundation, it is unclear. Was it the poets that corrupted Baghdad into hiding in its nights the sins of its citizens or the soil that lined the Tigris that somehow turned men into carriers of secret jealousies and desires, of thoughts about God and life that had to be hidden from the piercing gazes of the enthroned men they served? It's impossible to give an answer in all honesty.

It is easy to lay the blame on the air of Baghdad and on the populace of it, 
easier yet to lay the blame upon the Abbasids who had created the beautiful city out of nothing and who had seen personally to every aspect of the city, physical and spiritual, only to receive from within it some of the worse betrayals and insults in return.

What is difficult is to realize and accept the fact that there will always be moral ambiguities in history and in literature, that it will never be known for sure whether the Abbasids were patrons or oppressors, whether they "shaped" the literature produced under them or whether they merely nurtured talent under their wings.

It will never be known for sure, similarly, whether the litterateurs they put to death were blasphemers or dissidents, whether they truly posed a threat to society (as it is said with justifications of their murders in history books) or were they merely thorns in the eyes of spoilt, oppressive Caliphs?

It all boils down - the moral ambiguities, the unanswered questions, the glaring discrepancies especially in the characters of both intellectuals and patrons as sketched by historians - it all boils down to the simple poem written by the anonymous poet about the Abbasid Baghdad that was aptly titled "The Souls of Men are Sick" this essay so that the reader may leave with the taste of the disturbing yet haunting art that was born in eighth century Baghdad still fresh upon his or her tongue after reading this work to its last line;

Day and Night, I imagine the Arab land draw near.

Even as I am further from Najd and from its people too.

Baghdad is a mere despicable land,

Though life here has its comforts.

It is a land where men's souls are sick,

The stench even stronger when it rains.

\section{References:}

1 Snir, Reuven, Baghdad: The City in Verse, Harvard University Press, Cambridge, Massachusetts, London, England, 2013, p. 55

2 Al-Nawiri, Shahab-ul-Din, Nihayat-Ul-Arab fi Funun-il-Adab, Volume 22, Dar-ulKutub wal-Wathai'q al-qawmiyyah, Cairo, Egypt, 2002, p. 91

${ }^{3}$ Bobrick, Benson, The Caliph's Splendor, Simon \& Schuster, New York, United States of America, 2012, p. 19

4 Kennedy, Hugh, When Baghdad Ruled the World, 6th Edition, Da Capo Press, Cambridge, England, 2005, p. 75, 76

${ }^{5}$ Nicholson, Reynold, A Literary History of the Arabs, Cambridge University Press, London, England, 1966, p. 174

${ }^{6}$ For it was from Chinese prisoners that Muslims would learn the making of paper in Talas, Kazakhstan in 751 C.E.; the city's first paper mill, according to Philip Hitti in his History of the Arabs (10th edition, MacMillan Education Ltd., Hong Kong, China, 1992, p. 414), was established before the close of the eighth century in Baghdad. 
${ }^{7}$ Al-Tabari, Ibn Jarir, The History of al-Tabari, Vol. 30, translated by C.E. Bosworth, State University of New York Press, Albany, United States of America, 1989, p. 82-83

${ }^{8}$ Nicholson, Reynold Alleyne, A Literary History of the Arabs, p. 259

${ }^{9}$ Al-Tabari, Ibn Jarir, The History of al-Tabari, Vol. 29, translated by Hugh Kennedy, State University of New York Press, Albany, United States of America, 1990, p. 109

${ }^{10}$ Nicholson, A Literary History of the Arabs, p. 260

11 Ibid.

${ }^{12}$ Snir, Baghdad: The City in Verse, p. 55

${ }^{13}$ Kennedy, Hugh, When Baghdad Ruled the World, p. 41

${ }^{14}$ Nicholson, A Literary History of the Arabs, p. 290

${ }^{15}$ Al-Ruwaily, Hamdah Musharik, Shu'ara'il-zuhd wal Majun fi al-Shi'r al-Abbasi Hatta Nihayat al-Qarn al-Rabi' al-Hijri, Majallat Buhuth Kulliyat-il-Adaab, Vol. 31, University of Menoufiya, Menoufiya, Egypt, 2020, Pg. 780

${ }^{16}$ Snir, Baghdad: The City in Verse, p. 53

17 Nicholson, Reynold, A Literary History of the Arabs, p. 214

18 Hussein, Taha, Hadeeth ul-Arbia'a, Hindawi Foundation for Education \& Culture, Cairo, Egypt, 2012, p. 478

19 Ibid.

${ }^{20}$ Hussein, Taha, Hadith al-Arbia'a. p. 478

${ }^{21}$ Ibid., p. 483

22 Nicholson, A Literary History pf the Arabs, p. 214

23 Ibid., p. 215

24 Ibid.

25 Hurt, Clement, A History of Arabic Literature, Appleton \& Company, New York, United States of America, 1903, p. 71

26 Ibid

${ }^{27}$ Nicholsn, A Literary History of the Arabs, p. 215

28 Ibid.,

${ }^{29}$ Snir, Baghdad: The City in Verse, p. 73

30 All names mentioned except that of Mecca refer to places located inside or around Baghdad and were infamous for their taverns.

31 Hurt, Clement, A History of Arabic Literature, p. 70

32 Ibid., p. 66

33 Mallette, Karla, The Metropolis \& its Languages - Baghdad and Venice, Cosmopolitanism \& the Middle Ages, edited by Ganim, John, Palgrave Macmillan, New York, 2013, p. 26

34 Ibid., p. 67

${ }^{35}$ Nicholson, A Literary History of the Arabs, p. 217

36 Nicholson mentions both this and another version of the reason behind Abu Al'Atahiya's denouncement of court life; the fact that he had tired of the hypocrisy of the other court poets as well as the immorality of court life in Baghdad.

37 Al-Masudi, Abul-Hassan, Meadows of Gold, Translated by Lunde, Paul \& Stone, Caroline, Routledge, Abingdon, Oxon, 2010, p. 44

${ }^{38}$ Nicholson, A Literary History of Arabs, p. 298 
${ }^{39}$ Ibid., p. 222

${ }^{40}$ Nicholson, A Literary History of the Arabs, p. 299, 300

${ }^{41}$ Ibid., p. 297

42 Ibid., p. 297

${ }^{43}$ Mallette, Karla, The Metropolis \& its Languages - Baghdad and Venice, p. 24

${ }^{44}$ It is to note that it would be unjust and grossly generalizing on the part of the author to write "Muslim" scholars here and would negate the presence of Non-Muslim scholars present and academically active in the Abbasid empire.

${ }^{45}$ Mallette, Karla, The Metropolis \& its Languages - Baghdad and Venice, p. 26

${ }^{46}$ Ibid., p. 24

${ }^{47}$ Weidner, Genevieve, Popular Literature in the Abbasid Caliphate: How it Represented and Defined the Culture of the Abbasids, University of Massachusetts Undergraduate History Journal 1: Vol 1, Article 2, Amherst, 2017, p. 5

${ }^{48}$ Nicholson, Literary History of the Arabs, p. 346

${ }^{49}$ Kalila and Dimnah, ed. Wood, Ramsay, Rochester: Inner Traditions International, 1980,60

${ }^{50}$ Weidner, Genevieve, Popular Literature in the Abbasid Caliphate: How it Represented and Defined the Culture of the Abbasids, p. 7

${ }^{51}$ Hitti, Philip. K. History of the Arabs, $10^{\text {th }}$ edition, MacMillan Education Ltd., Hong Kong, China, Pg. 308.

${ }^{52}$ Nicholson, A Literary History of the Arabs, p. 192

53 Ibid.

${ }^{54}$ Nicholson, A Literary History of Arabs, p. 261

${ }^{55}$ Ibid., p. 260

${ }^{56}$ Nicholson, A Literary History of the Arabs, p. 373

${ }^{57}$ Ibid., p. 375

58 Ibid., p. 388

${ }^{59}$ Ibid., p. 253

${ }^{60}$ Kennedy, Hugh, When Baghdad Ruled the World, p. 30

${ }^{61}$ Levy, Reuben, A Baghdad Chronicle, Cambridge University Press, New York, United States of America, 1929, p. 48

${ }^{62}$ Ibn al-Nadim, al-Fihrist, al-Matba'ah al-Rahmaniyyah, Egypt, p. 341

${ }^{63}$ Levy Reuben, A Baghdad Chronicle, p. 46

${ }^{64}$ Al-Masudi, Meadows of Gold, T. by Lunde \& Stone, p. 388

${ }^{65}$ Nicholson, A Literary History of the Arabs, p. 261

${ }^{66}$ Snir, Baghdad: The City in Verse, p. 58

${ }^{67}$ Mallette, Karla, The Metropolis \& its Languages - Baghdad and Venice, p. 24

${ }^{68}$ Which is not to say he didn't, still. While Nicholson in his literary history has largely ignored Bashshar, Hugh Kennedy has mentioned him in detail on multiple point in his book which has been cited in this work.

${ }^{69}$ Nicholson, A Literary History of the Arabs, p. 270.

${ }^{70}$ Snir, Baghdad: The City in Verse, p. 58. 